\title{
Determination of Nd-Yag Laser Parameters for Metal Threads Cleaning in Textile Artefacts
}

\author{
BOJANA M. RADOJKOVIĆ, Institute "Goša", Belgrade, Serbia, \\ SLAVICA S. RISTIĆ, Institute "Goša”, Belgrade, Serbia \\ Original scientific paper \\ MILORAD M. ZRILIĆ, University of Belgrade, \\ Faculty of Technology and Metallurgy, Belgrade, \\ SUZANA R. POLIĆ, Central Institute for Conservation in Belgrade, Belgrade
}

Textile samples with metallic threads from the collection of the Ethnographic Museum Belgrade were subjected to Nd:YAG laser irradiation in order to determinate certain parameters for successfully and safely clean corrosion products without degrading the surrounding material. Application of conventional cleaning methods did not give the expected results, and the implementation of laser technology was the next step. The Nd:YAG laser energy $150 \mathrm{~mJ}(1064 \mathrm{~nm})$ and $50 \mathrm{~mJ}(532 \mathrm{~nm})$ and pulse width $150 \mathrm{ps}$ was used. The commercial, Thunder Art Laser was also used. Effects of the irradiated areas was investigated by optical and SEM microscopy and EDX analysis.

Key words: Laser cleaning, Nd:YAG laser, corrosion, metallic threads, textile

\section{INTRODUCTION}

National and ethnographic museums have reach collections of national costumes, flags, uniforms, banners and home textiles [1-3]. A lot of them are embroidered with metallic threads.

Ethnographic Museum in Belgrade collects, store and study ethnographic heritage of the entire South Slav area. Around 30000 textile items are kept in the storerooms of the museum of which there are 3527 embroidered textile items [1].

Metallic threads are basically copper or zinc, silver or gold plated. Since these luxury threads were produced as combination of precious metals and organic fibers, embroidered clothing was sign of wealth and social status.

There are many types of metal threads: metal strips, wires, strip wound around a silk yarn and others. The thickness of the precious metal is some micron. The substrate of embroidered items is very often homemade cotton, flax, hemp, wool or mixed - colored materials [4].

Conditions where textiles artifacts are kept in mu

Author's address: Bojana Radojković, Institute "Goša", Belgrade, Milana Rakića 35

Paper received: 24.12.2014.

Paper accepted: 19.01.5015. seum, very often do not exactly satisfy the principles of preventive care. There are significant variations in humidity and temperature, which affects the textile ite$\mathrm{ms}$, especially those that are embroidered or woven with metallic threads [5-7]. Therefore, these items are generally in a poorer condition than those that do not contain metal, because of the extra stresses from the high mass of metal material and the multiplicity of degradation processes. Conservation of cultural heritage requires elimination of existing and prevention of future deterioration as efficiently as possible.

Although Ethnographic Museums in the world vests significant efforts to provide the necessary conditions for preventive protection of artifacts, corrosion is one of the most common problems that degrade metal parts and thus the whole textile samples [5-8]. Corrosion crusts are a mixture of number corrosion products with impurities from the surroundings. Under the influence of corrosion thread surface gradually tarnish during the time. It becomes brittle and less shiny. In addition to changes in the metal filament there were observed damages of textile in embroidered ornament parts and in fibers [5-7].

Conservators use different cleaning methods and in each of them they follow the principle for minimum intervention on the artifacts. There are numerous literatures that describe the classic methods and problems accompanying their implementation in cleaning and 
protection of textile objects with metallic threads $[6,7$, 8].

The complex problem of degraded metal threads on ethnographic textiles was not possible to solve with the classical methods used in the process of conservation. Immersion process that takes place in chemical or electrolytic corrosion cleaning techniques may damage the fibers and dissolve any dye $[5,6,8,9]$ while mechanical cleaning removes the plating.

With the development of scientific and technological achievements, expansion of its application in everyday life is notably. Therefore, in cultural heritage objects conservation, the application of new technologies that showed the advantages over conventional methods is increasingly accepted. Laser techniques are among the most important techniques which show good properties in the cleaning. Their application is still being examined because of the complex process of the laser beam and different materials that can be met in cultural heritage (images, multi-colored paper documents, ceramic items, glass, metal, textiles, etc.).

The use of lasers in cleaning the objects of cultural heritage in recent years has become a standard method in conservation due to the fact that laser is highly controllable and can remove the surface contaminants precisely and selectively [8-10]. The application of laser in cleaning stone is described in paper [8], marble in [10], glass $[11,12]$, ceramics $[13,14,15]$, wall painting [16], pictures on canvas and wood [17], metal objects [9, 18-20], textile [21-24], other organic and biological samples [17] etc.

A laser is a source of high-intensity optical, infrared, or ultraviolet radiation produced as a result of stimulated emission. The laser beam is monochromatic, coherent and collimated so it can be focused in a fine spot. It can interact with a solid surface producing various effects, depending on the parameters such as laser intensity I, pulse duration $t$, and the properties of the surface [8-10]. Surface cleaning, based on laser ablation, is a delicate, critical and irreversible process, fraught with many potential complications. It is crucial to choose the most suitable laser cleaning methodology for each individual case, which involves optimizing the laser parameters in accordance with the material properties as well as the thorough knowledge of the ablation mechanisms involved [9].

In this context, a systematic investigation of potential damage or side effects occurring upon cleaning is essential and allows the fine-tuning of the operating parameters for a successful cleaning intervention. Optimization of laser cleaning is important concept of conservation and is the subject of numerous studies in the world. There are many investigations in area of determination of laser parameters for cleaning metal threads on embroidered textiles [2528].

This paper shows the results of research conducted with the aim of determining optimum parameters in the cleaning process of the corrosion product on textile samples with metallic threads, from the collection of the Ethnographic Museum in Belgrade. The cleaning results obtained by Nd:Yag lasers were studied with the aid of optical microscopes and electronic microscope SEM, with EDX analysis.

\section{SAMPLE DESCRIPTION}

The skirt Bojče (figure 1a) was traditional, female skirt dated to the nineteen century. It is opened on the whole length and covers only the hips reaching to the knees. It represents the part of festive Serbian female costume "Srpkinja" from the areas of Kosovo and Metohija and Raska. It is ornamented with embroidery or is mainly woven with multicolored pattern. It is woven on domestic loom. Base braider material are the cotton uncolored yarns. The weft is made of wool yarn, colored by stable herbal dyes, and metallic threads [1].

The sample used in this experiment is shown in figures $1 \mathrm{~b}$ and $1 \mathrm{c}$.

The examined skirt is decorated with geometric pattern embroidered with metal threads that is silver plated copper wound around natural fiber-cotton. Visual inspection revealed that investigated object has accumulated dust and dirt, mainly due to many years of bad storage under unsuitable conditions. One can see easily that the embroidery of metal threads is in poor condition.

a)

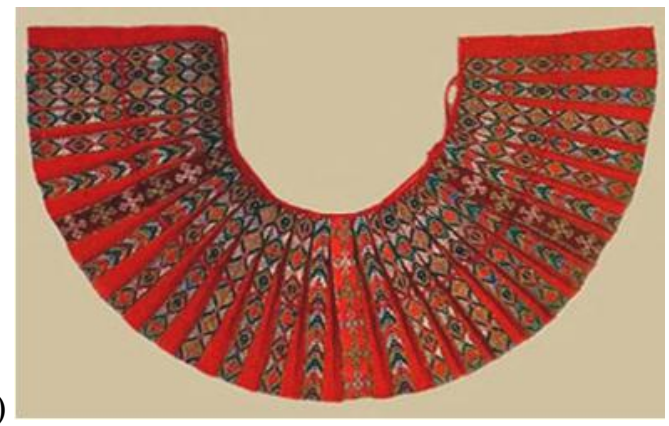

b)

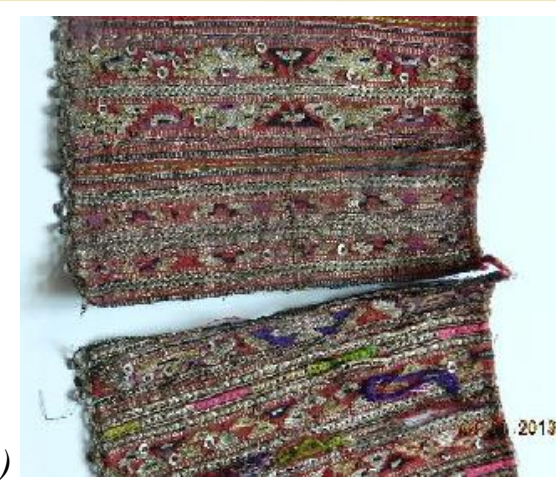


c)

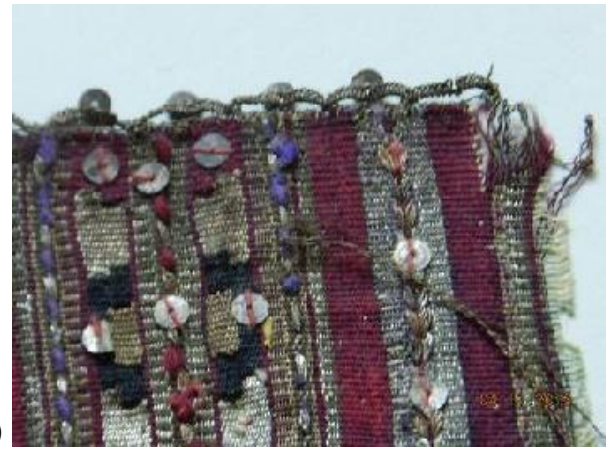

Figure 1 - a) skirt Bojče, b) and c) the skirt Bojce with corroded metallic treads

The textile fabric suffered greatly from aging and poor storage conditions and it contains a black stain, dust and dirt. Furthermore, USB optical microscope images show that there are corrosion products in fibers as on the surface of the metal parts (figure $2 a$ and $2 b$ ). They indicate that there is sediment on the surface of the sample, meaning that the surface is covered with crystals of metal or various salts. In cases of advanced processes, surfaces are completely covered in the initial phase, while in places where the creation of salt just begun the changes are sporadic.

To solve this problem some examinations were carried out in the last fifteen or more years. Some research showed that phosphine $\left(\mathrm{PH}_{3}\right)$, used as fumigant, can react with metal, particularly with copper, zinc, silver and gold, whereas high temperature, relative air humidity, as well as possible presence of ammonia accelerates the reaction. Various corrosion products are created in the process [5-7].
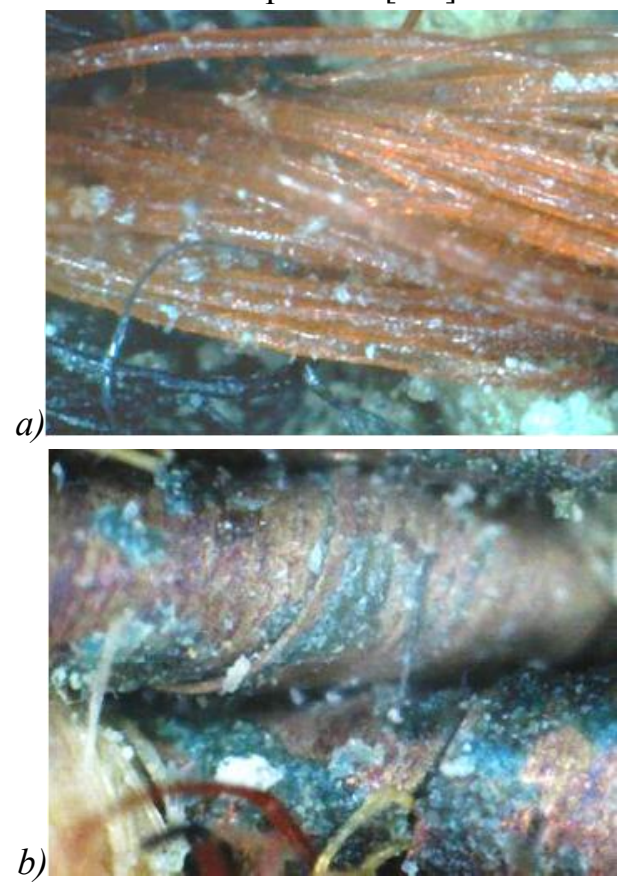

Figure 2 - OM images of corrosion products on a) organic fibers, b) surface of the metal
On SEM images of non-cleaned sample area, corrosion effects on surface of metal and on fibers are also visible (figure 3). EDX spectrums (figures $3 \mathrm{a}, 3 \mathrm{~b}$ and $3 \mathrm{c}$ ) in selected surface segments give averaged values of mass fraction of present elements: $3 \mathrm{a}$ on the metal threads, $3 \mathrm{~b}$ on fiber within the metal thread and $3 \mathrm{~d}$ on textile. Table 1 shows the mass fraction of the element expressed in \%. Metallic thread is basically copper with the silver layer. In every part, especially on those that are non-metallic, there are registered high percentage of $\mathrm{C}$ and $\mathrm{O}$. The presence of chlorine, phosphorus and sulfur are registered too.
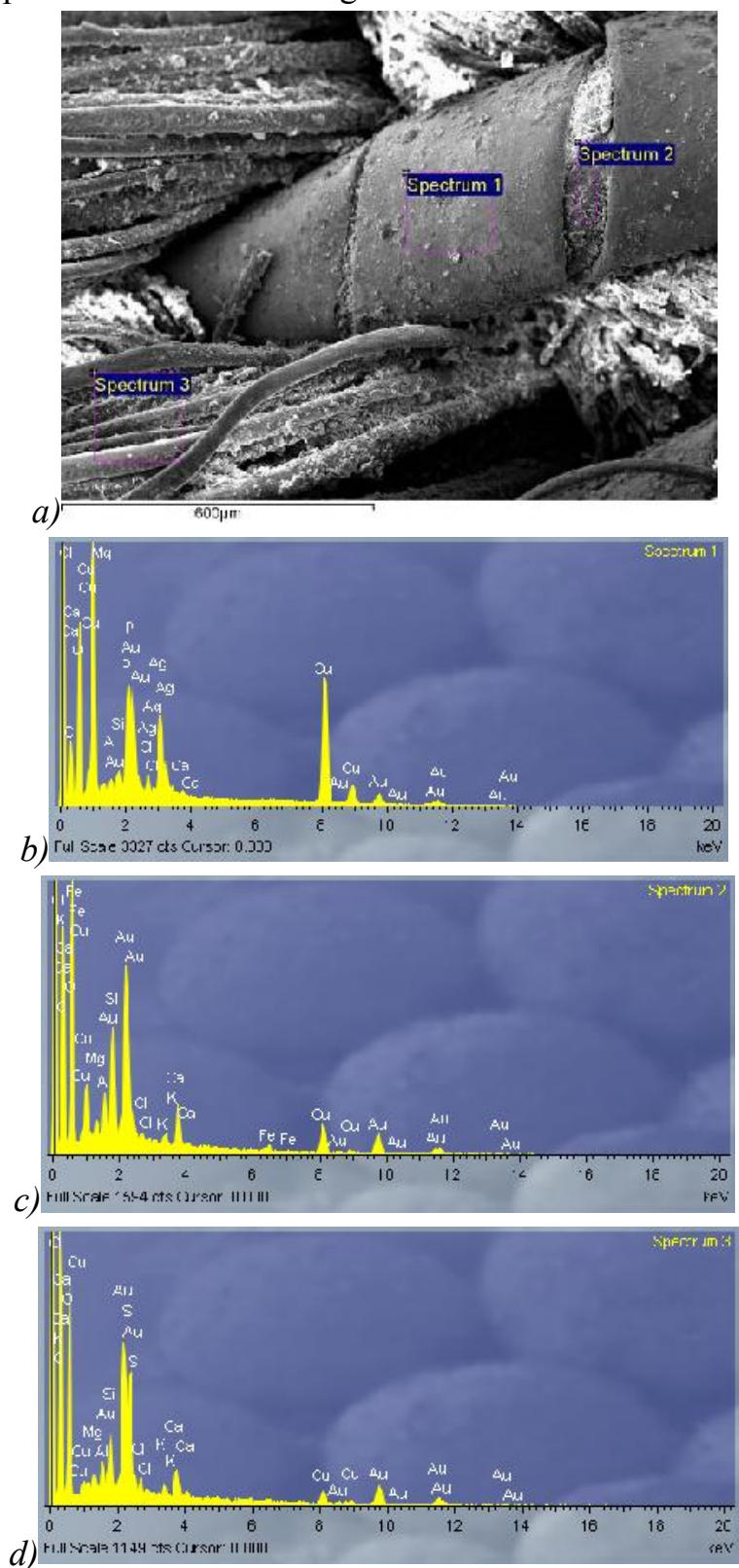

Figure 3-a) SEM image of the non-cleaned textile and metal threads with location for EDX analysis points and EDX spectrums for b) metal thread surface, c) core natural fiber, and d) wool yarn of textile. 
Table 1. Mass fraction of the presented element of non-cleaned zone (oxygen by stoichiometry normalized)

\begin{tabular}{|l|c|c|c|c|c|c|c|c|c|c|c|c|c|c|}
\hline Spectrum & C & O & Mg & Al & Si & P & S & Cl & K & Ca & Fe & Cu & Ag & Total \\
\hline Spectrum 1 & 26.09 & 37.26 & 0.33 & 0.36 & 0.35 & 2.80 & & 0.52 & & 0.21 & & 25.21 & 6.87 & 100.00 \\
\hline Spectrum 2 & 39.10 & 50.06 & 0.43 & 0.99 & 2.22 & & & 0.28 & 0.26 & 1.43 & 0.44 & 4.78 & & 100.00 \\
\hline Spectrum 3 & 47.17 & 44.92 & 0.38 & 0.54 & 0.93 & & 2.73 & 0.45 & 0.27 & 0.87 & & 1.75 & & 100.00 \\
\hline
\end{tabular}

\section{EXPERIMENT}

The sample was irradiated by two types of pulsed $\mathrm{Nd}$ :YAG laser. The first Nd:YAG laser is commercial system developed at EKSPLA Company, model SL212/SH/FH, with the following characteristics: wavelengths 1064 or $532 \mathrm{~nm}$; optical pulse duration $150 \mathrm{ps}$ (FWHM); output pulse energy $55 \mathrm{~mJ}(1064 \mathrm{~nm})$ and $57 \mathrm{~mJ}(532 \mathrm{~nm})$. The laser beam was focused using quartz lens of $10 \mathrm{~cm}$ focal length.

Laser beams were directed perpendicularly to the specimen. All irradiations were performed in air at the pressure of 1013 mbar and standard relative humidity. Laser repetition rate was in the interval from 1 to 10 Hz. During irradiation process laser was running in the multimode or near-fundamental mode regime.

Second part of experiment was performed using a commercial Nd:YAG laser, Thunder Art Laser, product of Quanta System. The laser can operate with three wavelengths, $1064 \mathrm{~nm}, 532 \mathrm{~nm}$ and $355 \mathrm{~nm}$. It operates in Q-Switch mode. The duration of the pulse is $\mathrm{e}<8 \mathrm{~ns}$. Frequency is $20 \mathrm{~Hz}$, beam diameter $10 \mathrm{~mm}$. The energy of the laser beam can change as follows: for 1064 $\mathrm{nm}$ maximum energy $1000 \mathrm{~mJ}$, for $532 \mathrm{~nm}-550 \mathrm{~mJ}$ and least for wavelength $355 \mathrm{~nm}, 200 \mathrm{~mJ}$. It has a mobile, articulated arm through which the laser beam is conducted by the aid of seven mirrors and can approach the sample under different angles and at a different distance.

There were 5 zones on sample irradiated with different lasers parameters. The parameters for two zones are presented on table 2. Commercial laser with basic and first harmonic, but with a smaller number of pulses was used. Height energy, obtained by the laser radiation, result in rapid heating and explosive vapors. The shock wave of air vapor performs ablation and removes sediments.

Table 2. Nd:YAG (model SL212/SH/FH) Laser parameters of zones cleaning

\begin{tabular}{|l|l|l|l|}
\hline Zone & $\lambda(\mathrm{nm})$ & $\mathrm{E} \mathrm{mJ} / \mathrm{cm}^{2}$ & notification \\
\hline 1 & - & - & Non cleaned \\
\hline 3 & 532 & 57 & Nd:Yag \\
\hline 5 & 1064 & 55 & Nd:Yag \\
\hline
\end{tabular}

The morphology of the sample surface was recorded with USB optical microscope and scanning electronic microscope (SEM), JEOL JSM-6610LB.
SEM is linked to the energy dispersion $\mathrm{X}$ spectrometer (EDX), INSA350, for the preliminary analysis of the chemical composition of the sample. Before photographing the sample was steamed with $20 \mathrm{~nm}$ thick layer of gold, with the aim of increasing the electricconductivity, namely, obtaining a better quality of the picture of the sample and structure.

\section{RESULTS AND DISCUSSION}

Different effects on the surfaces of the tested samples have been shown during and after laser cleaning. The Nd:YAG laser has some difficulty in removing organic materials since they absorb poorly at shorter wavelengths. The use of pulsed near infrared and green Nd:YAG lasers for cleaning corroded metals is limited by the potential risk of surface melting and blackening due to thermal and photochemical changes. This process is very sensitive and correct operating parameters and care by the operator are required.

Figure 4a is a SEM image of the central part zone 3 (the zone irradiated with laser wavelength $\lambda=532 \mathrm{~nm}$ ) and zoomed segment (figure $4 b$ ).

Figure $5 \mathrm{a}$ present the zone 5 which is irradiated with laser wavelength $\lambda=1064 \mathrm{~nm}$. Segments of zone 5 are presented on figures $5 \mathrm{~b}$ and $5 \mathrm{c}$.

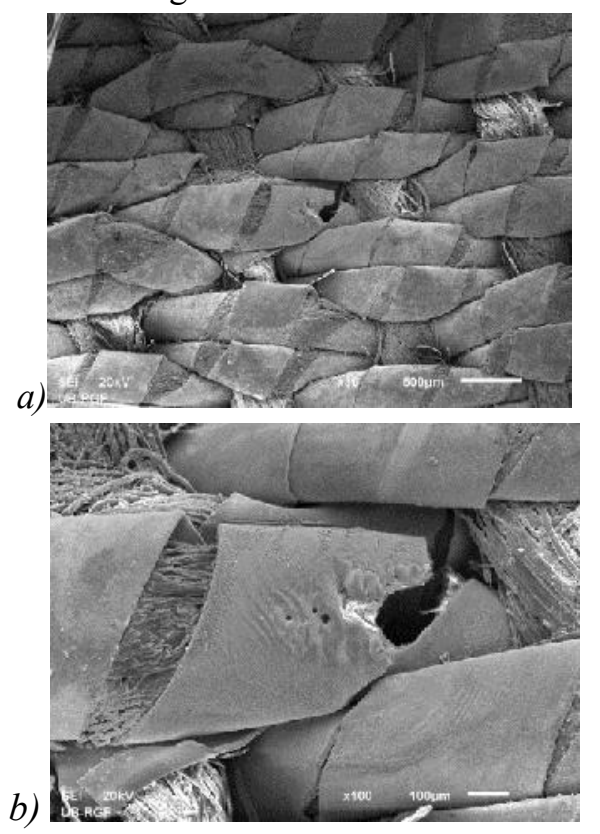

Figure 4 - SEM image zone $3 \lambda=532 \mathrm{~nm}, \Phi=57 \mathrm{~mJ}$ $/ \mathrm{cm}^{2}, n=400$ pulses of the a) central part b) zoomed segment (100x) 

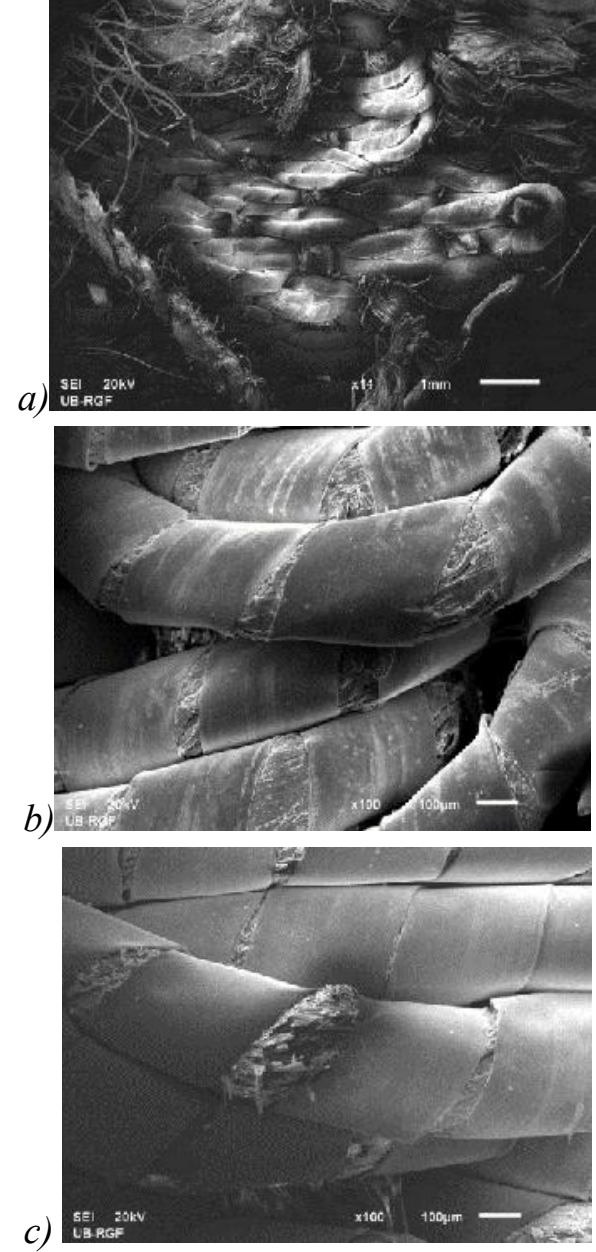

Figure 5 - SEM image zone $5 \lambda=1064 \mathrm{~nm}, \phi=55$ $\mathrm{mJ} / \mathrm{cm}^{2}, n=400$ pulses of the a) central part, b) and c) zoomed segments (100x)

Figure 6a shows the allocation of areas for which it was recorded EDX spectrum. The experimental results are given in figure $6 \mathrm{~b}$ and $6 \mathrm{c}$. Table 3 contains quantitative data on the chemical composition of the EDX analysis, expressed as a percentage of mass fractions. It is obvious that after the operation of the laser reduced the proportion of oxygen and carbon, and increased the proportion of metal elements. All other elements, in addition to chlorine and sulfur are eliminated.

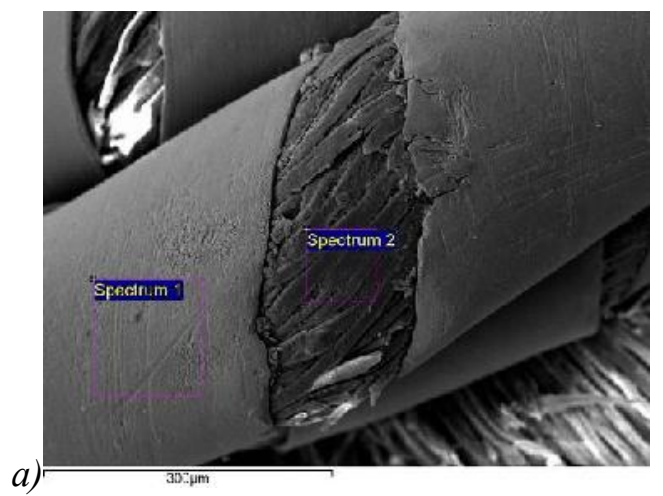

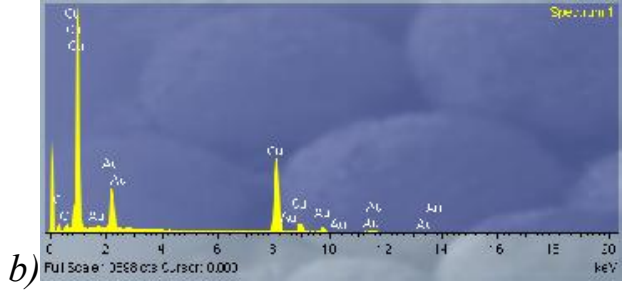

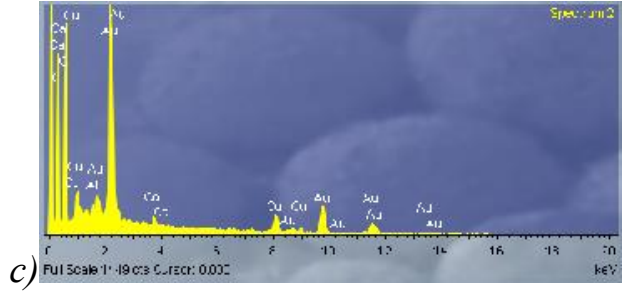

Figure 6-a) SEM image of the zone 5 with location for EDX analysis points, and EDX spectrums, b) metal thread, c) fiber.

The chemical compositions of the cleaned surfaces and the corrosion layers are different. The main components of the cleaned surface of the threads are $\mathrm{Cu}$ and $\mathrm{Ag}$; while in the corrosion products exist $\mathrm{C}, \mathrm{Mg}$, $\mathrm{Al}, \mathrm{Si}, \mathrm{P}, \mathrm{S}, \mathrm{Ca}$ and so on. On the uncovered, cleaned surfaces there was no signal from phosphorous and other elements detected on the initial layers. The signal from carbon was weak. However, the cleaned surfaces were oxidized.

Table 3. Mass fraction of the presented element of zone 5

\begin{tabular}{|c|c|c|c|c|c|c|}
\hline Spect. & $\mathrm{C}$ & $\mathrm{O}$ & $\mathrm{Al}$ & $\mathrm{Ca}$ & $\mathrm{Cu}$ & Total \\
\hline $\begin{array}{c}\text { Spect } \\
1\end{array}$ & 24.07 & 5.23 & & & 70.69 & 100.0 \\
\hline $\begin{array}{c}\text { Spect } \\
2\end{array}$ & 44.78 & 50.79 & 0.33 & 0.36 & 3.74 & 100.0 \\
\hline
\end{tabular}

Figure 7 shows the skirt Bojče with cleaned zones by Thunder Art Laser, product of Quanta System. The cleaning parameters are done in table 4 .

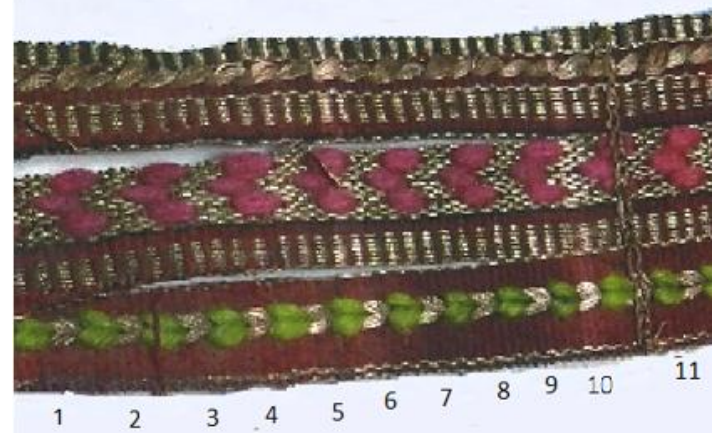

Figure 7 - Skirt Bojče with cleaned zones by Thunder Art Laser, product of Quanta System.

Zones 1-10 were dry and zone 11 was watered. The presence of moisture in the cleaned material contributes to increasing the efficiency of the sediments ablation, whether it is dirt or corrosion products. The tests show that the watered sprayed zones have better cleaning results. 
Table 4. Parameters for Thunder Art Laser cleaned zones

\begin{tabular}{|c|c|c|c|c|c|c|c|c|c|c|c|}
\hline zone & 1 & 2 & 3 & 4 & 5 & 6 & 7 & 8 & 9 & 10 & $11^{*}$ \\
\hline 䒠 & d & $\tilde{n}$ & $\tilde{n}$ & $\tilde{n}$ & $\tilde{n}$ & $\tilde{n}$ & 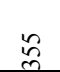 & in & nn & 丘 & ț \\
\hline 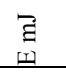 & 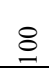 & $\infty$ & 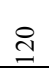 & $\stackrel{8}{0}$ & సి & $\underset{\sim}{\mathbb{N}}$ & ㄱ. & $\infty$ & 早 & $\stackrel{8}{0}$ & 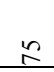 \\
\hline
\end{tabular}

\section{CONCLUSION}

The combined use of laser irradiation and SEM analysis can be applied to clean and study ancient textiles with silver threads. The obtained experimental results can be considered as a very important study of corrosion and dirt removal without impinging the original textiles and metal threads. Laser cleaning of metal threads is used, but side effects that modify the appearance of the materials, are not yet eliminated. Our results confirm that, if lower laser fluence for cleaning is applied, less damage occurs, but sometimes the cleaning may completely modifies the appearance of the material (the change of surface color at the heataffected zone in and around the laser-irradiated surface). In laser cleaning processes must be included textile professionals and conservators, since they may give precise guidelines for future tests in optimization the cleaning parameters.

The results confirm that shorter wavelength provided higher removal efficiency and lower threshold laser fluence for the removal of the surface corrosion and dirt layers. A shorter wavelength such as UV radiation $(355 \mathrm{~nm})$ is much more effective and efficient for cleaning the silver threads since it does not provide any apparent damages both on the cotton inside metal treads (fig.8 and table 4)

The results of tests show that the water sprayed surface of the sample can be well cleaned with much lower laser fluence. This is very important due to successful, safely laser cleaning of ancient textiles with corroded silver threads.

Another important conclusion is related to the effect of the laser impact on the long term conservation of the museum textile items, such as collections of uniforms, national costumes, flags, banners and home textiles in National, ethnographic and military museums.

The further tests have to be conducted to determine how reactive the metal is after cleaning. If it does become more reactive, a cleaning process may not be advisable. In such case, the artifacts have to be placed in a very pure environment.

Optimal laser cleaning of artifacts does not only refer to quality and economic parameters, which are efficiency, effectiveness, and speed, but most importantly it's about the safety of the artifacts during conservation.

\section{ACKNOWLEDGEMENTS}

The research was sponsored by the Ministry of Education, Science and technological development of the Republic Serbia, through projects number TR 34028, TR 35046.

\section{REMARK}

This paper was presented at $13^{\text {th }}$ Young Researchers Conference Materials Science and Engineering, Belgrade, December 10-12, 2014.

\section{REFERENCES}

[1] http://etnografskimuzej.rs/rs/zbirke/

[2] http://www.muzej.mod.gov.rs/en/museumactivity/collections/collection-ofuniforms\#.U5Bou5pZrcs

[3] http://www.imus.org.rs/d_exhibitions.php?jz=0

[4] http://conferences.saxo.ku.dk/traditionaltextilecra $\mathrm{ft} /$ keynote_speakers/presentations/Anna_Karatzan i.pdf

[5] Radovanović, D., Degradacija metalne niti na tekstilnim predmetima $\mathrm{u}$ etnografskom muzeju u Beogradu, Etnografski muzej u Beogradu, 30s, 2008.

[6] Sokolović Z., "Metode preventivne zaštite tekstilnih predmeta u muzeju", GEM u Beogradu, 72, p. 159-164, 2008.

[7] Sebenji, F., Hakl, L., Korozija metala, Tehnička knjiga, Beograd, 230s, 1980.

[8] Polic-Radovanovic, S., Primena lasera u obradi, zaštiti i dijagnosticiranju materijala predmeta kulturne baštine, doktorska disertacija, Univerzitet u Beogradu, 217s, 2007.

[9] Rode A., Baldwin K.G.H., Wain A., Madsen N.R., Freeman D., Delaporte Ph., Luther-Davies B., Appl. Surf. Sci. 254, 10, p. 3137-3146, 2008.

[10]Ortiz P., et al., Appl. Surf. Sci. 283, p. 193-201, 2013.

[11]Polić-Radovanović S., Ristić S., Stasić J., Trtica M., J. Non-Cryst. Solids, 358, 22, p. 3048-3056, 2012.

[12]Radojković B., Ristić S., Polić-Radovanović S., FME Transactions, 41, 2, p. 109-113, 2013.

[13]Pradell T., Molera J, Smith A., Climent-Font A., Tite M., J. Cult. Herit. 9, Supplement, p. e123e128, 2008. 
[14]Ristić S., Polić S., Radojković B., Striber J., PAC 8, 1, p. 15-23, 2014.

[15]Ristic S., et al., J. Russ. Laser Res., 31, 4, p. 401$412,2010$.

[16]Bordalo R. et all, Laser Chemistry, 2006, Article ID 90279, 9 pages, doi:10.1155/2006/90279

[17]Carmona N., Oujja M., Roemichc H., Castillejo M., Appl. Surf. Sci., 257, 23, p. 9935-9940, 2011.

[18]Pini R., Siano S., Salimbeni R., Pasquinucci M., Miccio M., J. Cult. Herit. 1, Supplement 1, p. S129-S137, 2000.

[19]Katavić B., Ristic S., Polic-Radovanovic S., Nikolic Z., Puharic M., Kutin M., Chem. Ind., 64, 5, p. 447-452, 2010.

[20]Šijački-Žeravcic V., Srećković M., Vedlin B., Ristić S., Proceedings of the Int. Conf. on Lasers 98., Ed. V.J. Corcoran and T.A. Corcoran SOQuE, STS Press, Mc Lean, p. 993-1001, 1999.
[21]Abdel-Kareem O., Harith M., Appl. Surf. Sci., 254, 18, p. 5854-5860, 2008.

[22]Ferrero F., Testore F., Tonin C., Innocenti R., AUTEX Research Journal, 2, 3, p. 109-114, 2002.

[23]Belli R., Miotello A., Mosaner P., Toniutti L., Appl. Surf. Sci., 247, 1-4, p. 369-372, 2005.

[24]Abdel-Kareem O., Journal of textile and Apparel, Technology and Management, 7, 2, p. 1-12, 2011.

[25]Degrigny C., Tanguy E., Le Gall R., Zafiropulos V., Marakis G., J. Cult. Herit. 4, Suplement 1, p.152-156, 2003.

[26]Lee J., Yu J., Koh Y., J. Cult. Herit., 4, Supplement 1, p. 157-161, 2003.

[27]Režić I., Ćurković L., Ujevic M., Talanta 82, 1, p. 237-244, 2010.

[28]Ristić S., Polić S., Radojković B., Proceed. of 6th international scientific conference, OTEH 2014, Belgrade, 09 - 10 October 2014, p. 649-655, 2014.

\section{SUMMARY}

\section{ODREĐIVANJE PARAMETARA ND:YAG LASERA ZA ČIŠĆENJE METALNIH NITI NA TEKSTILNIM ARTIFAKTIMA}

Tekstilni uzorak sa metalnim nitima iz kolekcije Etnografskog muzeja u Beogradu podvrgnut je laserskom zračenju Nd: YAG laserom u cilju rešavanja odredjenih parametara za uspešno i bezbedno čišćenje produkata korozije bez oštećenja okolnog materijala. Primena klasičnih metoda čišćenja nije dala očekivane rezultate i primena laserskih tehnologija je bio sledeći korak. U ispitivanju je korišćen Nd:YAG laser energija $150 \mathrm{~mJ}(1064 \mathrm{~nm})$ i $50 \mathrm{~mJ}(532 \mathrm{~nm})$ i dužine pulsa 150 ps. Takođe je korišćen $i$ komercijalni Thunder Art Laser. Efekti na ozračenim zonama ispitivani su optičkim i SEM mikroskopima $i$ EDX analizom.

Ključne reči: lasersko čišćenje, Nd:YAG laser, korozija, metalne niti, tekstil 